\title{
Upaya Mediasi dan Akibat Hukum Sengketa Pertanahan di Kantor BPN Kabupaten Sambas
}

\author{
Jamiat Akadol $^{1}$, Munadi ${ }^{2}$, Sri Sudono Saliro ${ }^{3}$, Samsul $^{4}$ \\ ${ }^{1}$ Institut Agama Islam Sultan Muhammad Syafiuddin Sambas, Jl. Raya Sejangkung No. 126, Sambas, 79463 \\ E-mail: srisudonosalirofh@gmail.com \\ ${ }^{2}$ Institut Agama Islam Sultan Muhammad Syafiuddin Sambas, Jl. Raya Sejangkung No. 126, Sambas, 79463 \\ E-mail: - \\ ${ }^{3}$ Institut Agama Islam Sultan Muhammad Syafiuddin Sambas, Jl. Raya Sejangkung No. 126, Sambas, 79463 \\ E-mail: - \\ ${ }^{4}$ Institut Agama Islam Sultan Muhammad Syafiuddin Sambas, Jl. Raya Sejangkung No. 126, Sambas, 79463 \\ E-mail: -
}

\begin{abstract}
Land is considered an asset that promises high value, so it is not surprising that land disputes occur in order to maintain ownership rights to land. The land dispute resolution process can be carried out by litigation or non-litigation. In the context of the implementation of land dispute resolution conducted at the Sambas BPN office, it is carried out through a mediation process (non-litigation). Based on the facts in the field in 2018 and 2019, there were many land disputes that were not resolved through mediation. This research focuses on what factors are causing the failure of mediation conducted at the Sambas BPN Office and how the legal consequences of resolving land disputes are resolved through mediation. The research uses empirical methods, and is analytical descriptive. To obtain primary data observation and unstructured interviews were conducted with respondents and sampling using purposive sampling. The results showed that: first, the factors causing the failure of mediation were the factors of the parties, the completion time factor, and supporting data factors. Second, the legal consequences of resolving land disputes resolved through mediation bind the parties to the dispute.
\end{abstract}

Keywords—: Mediation; Land Dispute; BPN Sambas.

\section{PENDAHULUAN}

Zaman sekarang perihal pertanahan bukanlah hal baru. Tentunya hal ini dikarenakan sebidang tanah yang terbatas tetapi memiliki nilai/harga yang tinggi dan merupakan kekayaan yang strategis. Secara esensial, makna dari kekayaan strategis sebidang tanah bagi kehidupan masyarakat Indonesia secara umum memiliki nilai ekonomis, nilai sosial-politik, nilai budaya, nilai pertahanan dan keamanan serta nilai legalitas hukum. ${ }^{1}$ Maka dari itu untuk menjamin nilai legalitas hukum, diperlukan dasar pengaturan hak kepemilikan tanah sebagai wujud perlindungan Negara dan mewujudkan legalitas hukum untuk warga negaranya. ${ }^{2}$ Dasar hukum hak kepemilikan tanah secara eksplisit diatur pada UU No. 5 Tahun 1960 Tentang Peraturan Dasar Pokok-Pokok Agraria (UUPA).

Kepemilikan hak atas tanah merupakan suatu kebutuhan manusia dan harus diwujudkan melalui pendaftaran tanah. Pemangku kebijakan membuat dasar ketentuan hukum pendaftaran tanah melalui ketentuan Peraturan Pemerintah. ${ }^{3}$ Dasar hukum pendaftaran tanah yakni PP No. 24 Tahun 1997 Tentang Pendaftaran Tanah. Dasar hukum ini menjamin legalitas hukum dan bentuk proteksi secara preventif dan represif guna memenuhi perlindungan hak asasi manusia. ${ }^{4}$ Selanjutnya untuk memperoleh legalitas hukum kepemilikan atas tanah maka dilakukan pendaftaran dan apabila segala syarat telah terpenuhi akan dikeluarkan sertifikat tanah atau surat tanda bukti hak.

Keberadaan sertifikat tanah memiliki fungsi sebagai dorongan sebuah tatanan hukum yang tertib, damai dan menciptakan suasana kondusif. ${ }^{5}$ Menurut Urip, ${ }^{6}$ sertifikat tanah merupakan alat bukti yang kuat dalam menunjukan status kepemilikan hak milik atas tanah, apabila sesuai kriteria sebagai berikut: a. sertifikat tanah harus atas nama subjek hukum baik orang ataupun badan hukum, b. cara memperoleh tanah dengan itikad baik, c. pengarapan tanah dikerjakan secara nyata, d. tidak ada pengajuan gugatan selama 5 tahun sejak sertifikat tanah terbit. Selain itu, pendaftaran tanah dilakukan pada badan yang secara resmi dan sah oleh Negara berdasarkan peraturan perundang-undangan yang berlaku, maka terbitan sertifikat tanah tersebut

\footnotetext{
${ }^{1}$ Rosmidah, “Kepemilikan Hak Atas Tanah Di Indonesia,” INOVATIF: Jurnal Ilmu Hukum Volume 6, no. 2, 2013 , hlm. 63-77.

${ }^{2}$ Nur Shivana, "Meraba Wujud Hak Asasi Manusia Di Negara Hukum,” Lex Scientia Law Review Volume 1 No. 1. 2017, hlm. 93-98.

${ }^{3}$ A.P Parlindungan, Pendaftaran Tanah Di Indonesia Cet. I, Mandar Maju, Bandung, 1999, hlm. 85.

${ }^{4}$ Arba, "The Legal Protection Of Community Right In Area Spatial Planning Of Mataram City Base On The Local Regulation Number 12 Year 2011," Jurnal IUS: Kajian Hukum Dan Keadilan Volume 2 Nomor 1. 2014, hlm. 28-41.

${ }^{5}$ Muhammad Yamin Lubis and Abdul Rahim Lubis, Hukum Pendaftaran Tanah. Mandar Maju, Jakarta, 2008 , hlm. 51.

${ }^{6}$ Urip Santoso, Pendaftaran Dan Peralihan Hak Atas Tanah, Cetakan II, Kencana, Jakarta, 2010, hlm. 261.
} 
memiliki kekuatan hukum yang kuat. ${ }^{7}$ Sehingga pemiliknya merasa aman dan tentram, dan segala sesuatunya akan mudah diketahui karena asas legalitas hukumnya jelas dan bisa di pertanggungjawabkan menurut hukum. ${ }^{8}$

Meskipun kriteria kepemilikan hak atas tanah telah dipenuhi sesuai peraturan hukum, bukan hal yang mustahil terjadi kasus pertanahan ${ }^{9}$, khususnya pada penelitian ini bicara mengenai sengketa pertanahan. Timbulnya sengketa pertanahan bermula adanya pengaduan dari subjek hukum yang mengutarakan keluhan-keluhan dan menuntut status kepemilikan hak atas tanah. ${ }^{10}$ Kantor BPN Sambas menerima pengaduan dengan catatan harus memenuhi syarat minimum yang harus ada, seperti: identitas pengadu/pelapor dan paparan singkat kasus sengketa pertanahan, apabila syarat minimum tersebut tidak terpenuhi maka petugas loket akan mengembalikan berkas pengaduan untuk dilengkapi oleh pengadu/pelapor. ${ }^{11}$ Keberatan dan tuntutan terjadi karena adanya perubahan, dan perilaku bersaing antara dua orang atau lebih dalam upaya mempertahankan status hak kepemilikan atas tanah. ${ }^{12}$

Di Indonesia macam-macam sengketa pertanahan secara garis besar meliputi: a) sengketa status kepemilikan hak atas tanah, b). peralihan/pemindahtanganan status hak kepemilikan atas tanah, c). membebankan hak kepada seorang individu, padahal status hak kepemilikan atas tanah masih tanggungan pihak lain. d). pendudukan eks tanah partikelir. ${ }^{13}$ Permasalahan sengketa pertanahan di masing-masing daerah tentunya berbeda-beda ${ }^{14}$, begitu juga di Kabupaten Sambas. Namun bentuk sengketa tanah yang kerap terjadi pada masyarakat mengenai sengketa kepemilikan (sengketa warisan, hibah, jual beli tanah), sengketa tumpang tindih, sengketa batas tanah, yang mana sengketa-sengketa tersebut merupakan pengakuan kepemilikan atas tanah. ${ }^{15}$

Setiap sengketa pasti diperlukan suatu kegiatan penyelesaian dan mustahil suatu sengketa akan berakhir tanpa adanya penyelesaian. ${ }^{16}$ Secara umum, proses penyelesaian kasus pertanahan di Indonesia mengenal 2 tipe, pertama, tipe penyelesaian proses litigasi, dan kedua tipe penyelesaian proses non litigasi. ${ }^{17}$ Menurut Nader, Todd, model penyelesaian sengketa yang tumbuh di lingkungan masyarakat dapat berupa: ajudikasi, mediasi, arbitrasi, negosiasi, pemaksaan, penghindaran, dan pembiaran. ${ }^{18}$ Jalur penyelesaian perkara melalui non litigasi merupakan cara menyelesaikan sengketa yang mana kedua belah pihak menyelesaikan sendiri dan tercapai kesepakatan/tidak ditentukan oleh kedua belah pihak atau dengan cara pihak pelapor dan terlapor melibatkan pihak ketiga/mediator yang bersifat tidak memihak salah satu pihak/netral. ${ }^{19}$ Pihak ketiga yang dimaksud adalah BPN, yang mana kronologi sengketa pertanahan tersebut diterima melalui loket pengaduan, surat ataupun website, dan akan dipelajari serta dianalisis guna melakukan serangkaian tindakan mediasi.

Berdasarkan data yang ditemukan pada kantor BPN Kabupaten Sambas pada tahun 2018 menerima 8 (delapan) pengaduan sengketa pertanahan untuk diselesaikan secara mediasi. Dari kedelapan pengaduan yang diajukan kepada kantor BPN Kabupaten Sambas sebanyak 7 pengaduan tidak terselesaikan melalui mediasi dan sebanyak 1 pengaduan telah terselesaikan melalui mediasi. Sedangkan pada tahun 2019 sebanyak 24 (dua puluh empat) pengaduan sengketa pertanahan. Dari 24 perkara tersebut, hanya 5 perkara yang telah terselesaikan melalui mediasi. Padahal upaya penyelesaian melalui mediasi dianggap lebih menguntungkan sebab proses tersebut lebih cepat, biaya tidak mahal, dan diselesaikan dengan hubungan baik kekeluargaan. ${ }^{20}$ Akan tetapi faktual dilapangan malah sebaliknya, banyak sengketa pertanahan tidak terselesaikan melalui mediasi.

Kabupaten Sambas adalah salah satu kabupaten perbatasan sebelah utara di Provinsi Kalimantan Barat yang luas daerahnya $6.395,70 \mathrm{~km}^{2}$ atau 4,36 persen luas daerah Kal-bar. ${ }^{21}$ Keadaan geografis Kab. Sambas yang sangat luas, tentu tidak bisa terhindar dari berbagai persoalan/kendala pertanahan yang dihadapi. Berdasarkan paparan diatas, penelitian ini ditulis untuk mengungkap fokus masalah yaitu: 1). bagaimana upaya penyelesaian melalui jalur mediasi yang dilakukan di Kantor BPN

\footnotetext{
${ }^{7}$ Dadi Arja Kusuma, Rodliyah, and Sahnan, "Sertifikat Hak Milik Atas Tanah Sebagai Alat Bukti Hak Yang Kuat,” Jurnal IUS: Kajian Hukum Dan Keadilan Volume 5 Nomor 2. 2017, hlm. 310-321.

${ }^{8}$ Boedi Harsono, Hukum Agraria Indonesia: Sejarah Pembentukan Undang-Undang Pokok Agraria, Isi Dan Pelaksanaannya, Penerbit Djambatan , Jakarta, 2007, hlm. 31.

${ }^{9}$ Terdapat didalam Peraturan Menteri Agraria dan Tata Ruang/Kepala Badan Pertanahan Nasional Republik Indonesia Nomor 11 Tahun 2016 Tentang Penyelesaian Kasus Pertanahan. Pasal 1 angka 1 bahwa Kasus Pertanahan adalah Sengketa, Konflik, atau Perkara Pertanahan untuk mendapatkan penanganan penyelesaian sesuai dengan ketentuan peraturan perundang-undangan dan/atau kebijakan pertanahan.

${ }^{10}$ Rusmadi Murad, Penyelesaian Sengketa Hukum Atas Tanah. Mandar Maju, Bandung, 1991, hlm. 22.

${ }^{11}$ Wawancara, Ilyas sebagai Staf Seksi Penanganan Masalah dan Pengendalian Pertanahan, di Kantor BPN Kab. Sambas, Tanggal 17 Februari, 2020.

${ }^{12}$ Asmawati, "Mediasi Salah Satu Cara Dalam Penyelesaian Sengketa Pertanahan,” INOVATIF: Jurnal Ilmu Hukum Volume 7, no. 1, 2014, hlm. 54-66.

${ }^{13}$ Yudha Chandra Arwana and Ridwan Arifin, "Jalur Mediasi Dalam Penyelesaian Sengketa Pertanahan Sebagai Dorongan Pemenuhan Hak Asasi Manusia," Jambura Law Review Volume 1, no. 2, 2019, hlm. 212-236.

${ }^{14}$ Elza Sharif, Mentuntaskan Sengketa Tanah Melalui Pengadilan Khusus Pertanahan. KPG, Jakarta, 2012, hlm. 12.

${ }^{15}$ Layyin Mahfiana, "Sengketa Kepemilikan Hak Atas Tanah Di Kabupaten Ponorogo,” KODIFIKASIA: Jurnal Penelitian Islam Volume 7, no. 1, 2017, hlm. 83-102.

${ }^{16}$ Mochamad Munir, "Penggunaan Pengadilan Negeri Sebagai Lembaga Untuk Menyelesaikan Sengketa Dalam Masyarakat”, Disertasi, Universitas Airlangga, 1997, hlm. 185

${ }^{17}$ Umiyati, "Penyelesaian Sengketa Batas Tanah Yang Didasarkan Pada Alat Bukti Sertifikat Melalui Alternative Dispute Resolution,” Jurnal Spektrum Hukum Volume 6, no. 2, 2019, hlm. 39-51.

${ }^{18}$ Nader and Todd, The Disputing Process Law in Ten Societas. Colombia University Press, New York, 1978, hlm 15.

${ }^{19}$ Maria SW Sumarjono, Mediasi Sengketa Tanah. Kompas, Jakarta, 2008, hlm. 2.

${ }^{20}$ Umiyati, Op.Cit. hlm. 39.

${ }^{21}$ Indah Huruswati, dkk, Evaluasi Program Pembangunan Kesejahteraan Sosial Di Desa Perbatasan - Kalimantan Barat 2012. P3KS Press, Jakarta, 2012, hlm. 11.
} 
Sambas; dan 2) bagaimana akibat hukum bagi para pihak apabila upaya penyelesaian sengketa pertanahan melalui jalur mediasi menemukan kesepakatan.

\section{TINJAUAN TEORITIS}

Pengkajian pustaka dalam penelitian ini mendasarkan pada beberapa hasil penelitian skripsi dan hasil penemuan-penemuan yang telah dibukukan dari beberapa penulis. Ada beberapa skripsi yang membahas tentang masalah sengketa tanahtetapi dengan objek yang berbeda diantaranya, Pertama, skripsi Riki Dendih Saputra yang berjudul "Penyelesaian Sengketa Kepemilikan Tanah yang Bersertifikat Ganda Menurut Aturan Badan Pertanahan Nasional di Wilayah Tangerang Selatan". ${ }^{22}$ Skripsi ini membahas faktor penyebab sertifikat ganda yang diterbitkan oleh Badan Pertanahan Nasional dan menganalisis penyebab masyarakat di wilayah Tangerang tidak memiliki sertifikat kepemilikan tanah. Hasil penelitian ini menunjukan bahwa persengketaan atas sertifikat tanah berganda sering ditemukan di wilayah kantor BPN, baik antar personal, dengan perusahaan, maupun dengan pemerintahan Tangerang Selatan. Sementara itu, model yang dilakukan untuk menyelesaikan persengketaan tanah selalu ditempuh melalui jalur hukum (pengadilan negeri sampai MA). Bedanya dengan penelitian penulis yakni penulis lebih memfokuskan pada upaya non-litigasi (mediasi), sedangkan skripsi Riki Dendih Saputra mengungkapkan upaya peneyelesaian sengketa tanah melalui jalur litigasi (pengadilan).

Kedua, penelitian yang dilakukan oleh Dewi Zulkharnain dengan judul "Bentuk Penyelesaian Terhadap Sertifikat Ganda (Overlapping) Antara Sertifikat Hak Guna Bangunan Dengan Sertifikat Hak Milik Oleh Badan Pertanahan Nasional Kota Surabaya II". ${ }^{23}$ Penelitian skripsi ini membahas bahwa munculnya sertifikat ganda ditengarai oleh faktor-faktor yang mempengaruhi timbulnya sertifikat ganda antara lain karena ketidaktelitian pejabat kantor pertanahan, peta pendaftaran dan kesengajaan pemohon tidak memberikan keterangan yang tidak benar dan untuk memperoleh keuntungan pribadi dan akibat hukum dari penerbitan sertifikat ganda. Dan akibat hukum dari penerbitan sertifikat ganda adalah menimbulkan ketidakpastian hukum, menimbulkan kerugian dan pembatalan sertifikat. Perbedaanya penelitian penulis yakni objek penelitian penulis yang dibahas sengketa sertifikat tanah melalui upaya mediasi dan akibat hukumnya, sedangkan skripsi Dewi Zulkharnain membahas objeknya sertifikat ganda dan penyelesaiannya melalui pengadilan.

Selanjutnya Ketiga, jurnal ilmiah oleh Nia Kurniati dan Efa Laela Fakhriah, berjudul "BPN Sebagai Mediator Dalam Penyelesaian Sengketa Tanah Di Indonesia Pasca PERKABAN No. 11 Tahun 2016". ${ }^{24}$ Jurnal ini membahas tentang pemaparan permasalahan dalam penyelesaian sengketa tanah oleh BPN dan upaya penyelesaiannya. Objek penelitian ini yaitu sengketa tanah yang menjadi kewenangan BPN. Dengan cara mediasi berhasil dicapai kesepakatan akan dituangkan dalam "kesepakatan perdamaian" yang ditandatangani oleh para pihak dan mediator. Berita Acara Pelaksanaan Mediasi dibuat dan ditandatangani oleh mediator. Kesepakatan perdamaian ini semata-mata hanya merupakan alat bukti tertulis dan tidak mempunyai kekuatan hukum mengikat untuk dilaksanakan, melainkan masih memerlukan dukungan lembaga peradilan untuk memperoleh kekuatan hukum yang mengikat atas kesepakatan perdamaian. Perbedaannya terletak pada analisis yang digunakan, penulis menggunakan pendekatan analisis lapangan yang mengungkap persoalan nyata di BPN Kabupaten Sambas, sedangkan jurnal Nia Kurniati dan Efa Laela Fakhriah menggunakan pendekatan analisis kepustakaan, yang hanya terfokuskan pada pembahasan kewenangan BPN berdasarkan PERKABAN No. 11 Tahun 2016.

Penelitian ini berbeda dari skripsi dan jurnal yang telah dipaparkan tersebut yakni pembahasannya terfokuskan mengenai upaya mediasi dalam penyelesaian sengketa pertanahan di Kantor ATR/BPN Sambas dan serta menganalisis akibat hukum dari gagalnya mediasi dalam penyelesaian sengketa pertanahan di Kantor Kementerian ATR/BPN Kab. Sambas. Penelitian ini membahas tentang gagalnya mediasi yang disebabkan oleh pihak pelapor dan terlapor atau salah satu pihak tidak bersedia menghadiri mediasi, sehingga pelaksanaan mediasi ditunda atau bahkan tidak berjalan dengan efektif. Selain itu, akibat hukum dari gagalnya mediasi, akan dianalisis berdasarkan peraturan perundang-undangan yang berlaku dan dihubungkan dengan hasil temuan lapangan, sehingga dapat menjawab apakah akan dilakukan upaya hukum lain yang ditempuh selain mediasi.

\section{III.METODE PENELITIAN}

Metode Penelitian menggunakan metode empiris dengan lokasi penelitian di wilayah hukum Kantor BPN Sambas, penelitian ini bersifat deskriptif analitis. ${ }^{25}$ Penelitian ini tetap memanfaatkan data kuantitatif sengketa pertanahan dari BPN Sambas. Responden primer sekaligus data primer penelitian ini adalah pejabat BPN Sambas yang menangani bidang Penanganan Sengketa, Konflik, dan Perkara Pertanahan dengan menggunakan purposive sampling. ${ }^{26}$ Data sekunder berupa

\footnotetext{
${ }^{22}$ Riki Dendih Saputra, "Penyelesaian Sengketa Kepemilikan Tanah Yang Bersertifikat Ganda Menurut Aturan Badan Pertanahan Nasional Di Wilayah Tangerang Selatan". Skripsi, Fakultas Syariah dan Hukum UIN Syarif Hidayatullah Jakarta, 2017.

${ }^{23}$ Dewi Zulkharnain, "Bentuk Penyelesaian Terhadap Sertifikat Ganda (Overlapping) Antara Sertifikat Hak Guna Bangunan Dengan Sertifikat Hak Milik Oleh Badan Pertanahan Nasional Kota Surabaya II". Skripsi, Fakultas Hukum, Universitas Pembangunan Nasional "veteran,” 2013.

${ }^{24}$ Nia Kurniati and Efa Laela Fakhriah, "BPN Sebagai Mediator Dalam Penyelesaian Sengketa Tanah Di Indonesia Pasca PERKABAN No. 11 Tahun $2016 ., "$ Sosiohumaniora LP2M Unpad Volume 19, No. 2, 2017, hlm. 95-105.

${ }^{25}$ Haris Herdiyansyah, Metode Kualitatif Untuk Ilmu-Ilmu Sosial. Salemba Humanika, Jakarta, 2012, hal. 9.

${ }^{26}$ M Atho Mudzhar, Pendekatan Studi Islam Dalam Teori Dan Praktek. Pustaka Pelajar, Yogyakarta, 1998, hal. 70.
} 
Website : http://yustisia.unmermadiun.ac.id/index.php/yustisia

peraturan perundang-undangan yang relevan dengan bidang pertanahan, buku, jurnal dll. Selanjutnya peneliti melakukan obsevasi dan wawancara tidak terstruktur dengan mengajukan pertanyaan dan dikembangkan sesuai dengan jawaban dari responden. $^{27}$

\section{IV.HASIL PENELITIAN DAN PEMBAHASAN}

\section{A. Upaya Penyelesaian Melalui Mediasi}

Penyelesaian sengketa pertanahan melalui penyelesaian mediasi bisa saja menemukan kesepakatan untuk berdamai, tetapi tidak jarang juga menemukan kegagalan. Lembaga yang memiliki otoritas diwilayah hukum Kabupaten Sambas pada konteks penyelesaian sengketa pertanahan diluar pengadilan dan sebagai fasilitator sebelum menuju jalur pengadilan dilakukan oleh BPN Sambas. Pada proses pelaksanaan mediasi, pihak pelapor dan terlapor secara sukarela dan dengan itikad baik meminta bantuan kepada pihak ketiga atau mediator ${ }^{28}$, untuk dirundingkan, dimusyawarahkan secara adil, efisien dan biaya yang murah, dan hasil kesepakatannya dapat diterima pihak pelapor dan terlapor. ${ }^{29}$

Profesionalitas mediator sedikit banyak akan memberi pengaruh pada keberhasilan upaya penyelesaian melalui mediasi. Asumsinya bahwa peran mediator bisa memberikan pengaruh baik yang semula terjadi konflik antara pelapor dan terlapor, berubah dan memiliki persepsi yang sama untuk mencapai tujuan kesepakatan bersama yang saling menguntungkan. ${ }^{30}$ Sikap adil mediator ditunjukan dengan mampu menjaga kepentingan pihak pelapor dan terlapor dengan bijaksana, sehingga hal yang paling utama untuk dijaga adalah nilai kepercayaan para pihak kepada mediator. ${ }^{31}$ Mediator membantu memberikan gambaran alternatif penyelesaian dan mencarikan cara terbaik, solusi atas persoalan yang dihadapi dan mendorong para pihak secara bersama-sama ikut menyelesaikan sengketa. Berdasarkan hasil observasi dengan Dini Apriliani ${ }^{32}$ mengatakan bahwa kualitas keberhasilan mediasi ditentukan oleh sikap baik kedua belah pihak dalam memaknai mediasi, rasa saling percaya antar para pihak dan kepercayaan terhadap mediator dalam menyusun konsep kesepakatan yang sama-sama disepakati oleh para pihak yang bersengketa.

Hasil wawancara dengan Desmanto, ${ }^{33}$ bahwa proses pelaksanaan mediasi dalam menyelesaikan sengketa pertanahan di BPN Sambas memiliki 3 tahapan antara lain: pertama, tahap persiapan, kedua tahap kegiatan mediasi, ketiga, tahap hasil. Pada tahapan persiapan meliputi: BPN Sambas mempelajari awal mula permasalahan dan pokok permasalahan yang disengketakan, membentuk tim penyelesaian sengketa dan penentuan mediator, mempersiapkan bahan mediasi, menentukan waktu dan tempat pelaksanaan mediasi, dan mengirimkan undangan panggilan kepada para pihak untuk menghadiri pelaksanaan mediasi. Selanjutnya tahapan kegiatan mediasi dapat dilaksanakan apabila para pihak yang bersengketa (pelapor dan terlapor) hadir pada waktu pelaksanaan mediasi, sedangkan apabila hanya dihadiri oleh salah satu pihak, maka pelaksanaan mediasi akan ditunda dan dilakukan penjadwalan kembali pelaksanaan mediasi.

Pada konteks hasil mediasi terhadap sengketa pertanahan yang menemukan kesepakatan antar para pihak, maka selanjutnya menandatangani perjanjian perdamaian yang dibuat oleh BPN yang berisi kausul-kausul sebagaimana disepakati. ${ }^{34}$ Menurut Edi Supardi, ${ }^{35}$ Perjanjian perdamaian tersebut selanjutnya dilakukan pendaftaran di Kepaniteraan Pengadilan Negeri setempat guna mengikat dan menjamin para pihak dimata hukum yang kemudian selanjutnya disebut akta perdamaian. ${ }^{36}$ Sedangkan apabila upaya penyelesaian melalui mediasi tidak menemukan kesepakatan antar para pihak yang bersengketa, menurut hasil wawancara dengan Fajar Yulianto, ${ }^{37}$ sengketa pertanahan tersebut disarankan untuk ditempuh upaya hukum lainnya yaitu melalui lembaga litigasi/pengadilan, yang mana gugatan ditujukan kepada Pengadilan Tata Usaha Negara yang domisili hukumnya hanya ada di provinsi, atau mengajukan gugatan ke Pengadilan Negeri setempat.

Adapun faktor penyebab gagalnya penyelesaian sengketa pertanahan dengan cara mediasi di Kantor BPN Sambas, berdasarkan hasil observasi yang dilakukan kepada Kasi Penanganan Masalah dan Pengendalian Pertanahan, Kasubsi

\footnotetext{
${ }^{27}$ Norman K. Denzin, Yvonna S. Lincoln (editor), and Dariyatno (penerjemah), Handbook of Qualitative Research (Edisi Ketiga). Pustaka Pelajar, Yogyakarta, 2009, hlm. 507-508. Dalam buku Jamiat Akadol, Budaya Hukum Birokrasi Pelayanan Publik di Indonesia. Penerbit Deepublish Publisher, Yogyakarta, 2020, hlm. 39.

${ }^{28}$ Lihat pada Peraturan Menteri Agraria dan Tata Ruang/Kepala Badan Pertanahan Nasional Republik Indonesia Nomor 11 Tahun 2016 Tentang Penyelesaian Kasus Pertanahan. Mediator adalah pihak yang membantu para pihak dalam proses perundingan guna mencari berbagai kemungkinan penyelesaian sengketa atau konflik tanpa menggunakan cara memutus atau memaksakan sebuah penyelesaian.

${ }^{29}$ Nia Kurniati dan Efa Laela Fakhriah, Op.Cit. hlm. 96.

${ }^{30}$ Rachmadi Usman, Pilihan Penyelesaian Sengketa Di Luar Pengadilan. PT. Citra Aditya Bakti, Bandung, 2003, hlm. 2.

${ }^{31}$ Syahrizal Abbas, Mediasi Dalam Perspektif Hukum Syariah, Hukum Adat, Dan Hukum Nasional. kencana Prenada Media Group, Jakarta 2009, hlm. 43.

${ }^{32}$ Wawancara, Dinni Aprilliani, SH sebagai Kasubsi Penanganan Sengketa, Konflik, dan Perkara Pertanahan, di Kantor BPN Kab. Sambas, Tanggal 25 Februari, 2020

${ }^{33}$ Wawancara, Desmanto, SH sebagai Kasubsi Pengendalian Pertanahan, di Kantor BPN Kab. Sambas, Tanggal 17 Februari, 2020.

${ }^{34}$ Nia Kurniati dan Efa Laela Fakhriah. Op.Cit, hlm. 98.

${ }^{35}$ Wawancara, Edi Supardi sebagai Kasi Penanganan Masalah dan Pengendalian Pertanahan di Kantor BPN Kab. Sambas Tanggal 25 Februari, 2020.

${ }^{36}$ Akta Perdamaian adalah kesepakatan hasil mediasi dalam bentuk dokumen yang memuat ketentuan penyelesaian sengketa yang ditandatangani oleh para pihak dan mediator.

${ }^{37}$ Wawancara, Fajar Yulianto, SH sebagai Mediator dari Kasi Perdata dan Tata Usaha Negara pada Kejari Sambas, Tanggal 25 Februari, 2020.
} 
Penanganan Sengketa, Konflik, dan Perkara Pertanahan, dan Mediator dari Kasi Perdata dan Tata Usaha Negara pada Kejari Sambas dapat disimpulkan sebagai berikut:

a. Ketidakhadiran para pihak atau salahsatu pihak yang bersengketa, sehingga hal tersebut harus dilakukan pengaturan ulang pertemuan untuk dilangsungkan mediasi.

b. Para pihak/salah satu pihak tidak ada itikad baik untuk menyelesaikan sengketa.

c. Para pihak saling mempertahankan pendapat masing-masing individu yang tak kunjung berpenghujung. Hal ini dilakukan dengan penuh emosional, guna mempertahankan penguasaan tanahnya sehingga suasana menjadi tidak kondusif.

d. Waktu yang digunakan untuk memediasi satu perkara, memerlukan waktu yang cukup lama dan berulang-ulang.

e. Kurangnya arsip data yang dimiliki oleh pihak BPN Kab. Sambas sebagai data pembanding antara para pihak yang bersengketa. Kurangnya arsip data dikarenakan peristiwa Kantor BPN Kab. Sambas yang mengalami kebakaran.

Tidak jarang ditemukan ketika para pihak yang sudah gagal melakukan mediasi, tidak melakukan upaya hukum lain melalui pengadilan akan tetapi mencoba lagi untuk melakukan upaya penyelesaian sengketa melalui mediasi, yang tentunya dilakukan ketika suasana para pihak sudah tenang.

\section{B. Akibat Hukum Bagi Para Pihak yang Pelaksanaan Mediasinya Berhasil}

Kewenangan penyelesaian sengketa pertanahan dengan cara mediasi akan memberikan pengaruh pada keputusan yang disepakati secara bersama-sama, sehingga hasil kesepakatan tersebut bentuk keadilan, kemanfaatan dan sekaligus kepastian menciptakan perlindungan hukum. Makna keadilan pada penyelesaian sengketa pertanahan melalui mediasi mewakili keadilan antara para pihak yang bersengketa, pernyataan itu senada dengan keadilan yang uraikan oleh Satjipto Rahardjo, bahwa nilai keadilan didasarkan pada keinginan dan keseimbangan hak dan kewajiban dari masyarakat. ${ }^{38}$

Dengan demikian hasil mediasi oleh BPN RI bersifat autoritatif. ${ }^{39}$ Termasuk juga BPN Sambas, maksud dari bersifat autoritatif ialah pelaksanaan mediasi dalam menyelesaikan sengketa pertanahan membuat keputusan dari proses yang dilakukan oleh BPN Sambas terlaksana sesuai dengan kewenangan atribusi yang termuat dalam Peraturan Menteri Agraria dan Tata Ruang/Kepala Badan Pertanahan Nasional Republik Indonesia Nomor 11 Tahun 2016 Tentang Penyelesaian Kasus Pertanahan yang merupakan suatu lembaga memiliki wewenang menyelesaian sengketa pertanahan di luar pengadilan.

Dinni Aprilliani sebagai Kasubsi Penanganan Sengketa, Konflik, dan Perkara Pertanahan BPN Sambas ${ }^{40}$ mengungkapkan bahwa hasil kesepakatan dari pelaksanaan mediasi wajib untuk dibubuhi tandatangan oleh para pihak/pelapor dan terlapor yang bersengketa, mediator dan para saksi pada berita acara pelaksanaan mediasi. Penandatanganan dilaksanakan pada hari dan tanggal ketika menemukan kesepakatan antar para pihak bersengketa, dilakukan secara bersama-sama pada tempat yang tidak terpisah. Isi kesepakatan yang tertuang dalam berita acara pelaksanaan mediasi merupakan perumusan dari kedua belah pihak tanpa paksaan dan intimidasi. Isi berita acara pelaksanaan mediasi mengikat para pihak bersengketa.

Dasar utama tujuan mediasi memberikan putusan bersifat win-win solution. Edi Supardi sebagai Kasi Penanganan Masalah dan Pengendalian Pertanahan BPN Sambas mengungkapkan arti sifat win-win solution yakni sebuah kata sepakat yang bermakna untung sama untung. Setiap lembaga tentu memiliki metode yang berbeda-beda dalam menyelesaikan persengketaan, ada kelebihan dan kekurangannya masing-masing. ${ }^{41}$ Metode utama dalam proses pelaksanaan mediasi yaitu melakukan pendekatan secara emosional kepada kedua belah pihak, hal ini dilakukan agar kedua belah pihak berkenan untuk menghadiri pelaksanaan mediasi sebagaimana dijadwalkan oleh BPN, dan pada hasil mediasi akan menghasilkan keputusan yang menjaga kepentingan-kepentingan para pihak tetap terpenuhi.

Paparan diatas menunjukan bahwa pelaksanaan penyelesaian sengketa pertanahan jalur mediasi menekankan pada nilai manfaat bagi para pihak yang bersengketa. Dengan dasar penekanan nilai manfaat tersebut bisa mengakomodir kepentingan para pihak secara maksimal. Hal ini akan memberikan dampak positif baik itu terhadap kepuasan para pihak bersengketa akan hasil mediasi, kepercayaan para pihak kepada kepiawaian seorang mediator dan sebagai bukti bahwa mediasi itu cepat, singkat dan biaya murah. Inilah kelebihan secara substantif dari pelaksanaan mediasi dalam menyelesaiakansengketa pertanahan. Hal ini merupakan perwujudan dari makna keadilan pada sebuah implementasi hukum yaitu hasil keputusan tidak merugikan para pihak yang bersengketa atas keputusan yang disepakati bersama. Maka apabila dalam proses penyelesaian sengketa melalui mediasi yang dilakukan di Kantor BPN Kab. Sambas telah mencapai kesepakatan di antara para pihak yang bersengketa, semua kesepakatan dituangkan dalam akta perjanjian atau perjanjian perdamaian yang selanjutnya akan didaftarkan ke Kepaniteraan Pengadilan Negeri Sambas demi menjamin kepastian hukum dan mengikat para pihak yang bersengketa. ${ }^{42}$ Pada umumnya, akta perdamaian memiliki makna sama dengan penetapan eksekusi dari putusan pengadilan, karena akta perdamaian yang notabene merupakan dokumen hukum dan memiliki kedudukan yang sejajar dengan putusan pengadilan inkracht.

\section{KESIMPULAN}

\footnotetext{
${ }^{38}$ Satjipto Rahardjo, Hukum Progresif Sebuah Sintesa Hukum Indonesia. Genta Publishing, Yogyakarta, 2009 , hlm. 21.

${ }^{39}$ Nia Kurniati dan Efa Laela Fakhriah, Op.Cit. hlm. 101"

${ }^{40}$ Wawancara, Dinni Aprilliani, SH sebagai Kasubsi Penanganan Sengketa, Konflik, dan Perkara Pertanahan, di Kantor BPN Kab. Sambas, Tanggal 25 Februari.

${ }^{41}$ Wawancara, Edi Supardi sebagai Kasi Penanganan Masalah dan Pengendalian Pertanahan di Kantor BPN Kab. Sambas Tanggal 25 Februari.

${ }^{42}$ Direktur Jenderal Peraturan Perundang-Undangan Kementerian Hukum dan HAM RI, "Peraturan Menteri Agraria Dan Tata Ruang / Kepala Badan Pertanahan Nasional RI Nomor 11 Tahun 2016 Tentang Penyelesaian Kasus Pertanahan” (2016), Lihat Pasal 41.
} 
Hasil temuan penelitian dapat disimpulkan sebagai berikut: faktor penyebab gagalnya pelaksanaan penyelesaian sengketa pertanahan melalui mediasi disebabkan faktor ketidakhadiran para pihak/salah satu pihak, faktor keterbatasan waktu penyelesaian dikarenakan ketidakhadiran para pihak sehingga memerlukan waktu lama dan berulang-ulang , kendala selanjutnya disebabkan tidak adanya arsip dari Kantor BPN Kab. Sambas yang akan digunakan sebagai data pembanding. Akibat hukum dari penyelesaian sengketa pertanahan yang dilakukan melalui mediasi menemukan kesepakatan akan dituangkan dalam berita acara pelaksanaan mediasi, ditandatangani oleh para pihak dan mengetahui kepala BPN Sambas dan kemudian atas dasar berita acara mediasi pelaksanaan mediasi dibuatkan akta perdamaian serta melakukan pendaftaran ditujukan kepada Kepaniteraan Pengadilan Negeri Sambas sehingga mempunyai kekuatan hukum mengikat bagi para pihak.

\section{VI.DAFTAR PUSTAKA}

Abbas, Syahrizal. 2009. Mediasi Dalam Perspektif Hukum Syariah, Hukum Adat, Dan Hukum Nasional. Jakarta: kencana Prenada Media Group.

Arba. (2014). "The Legal Protection Of Community Right In Area Spatial Planning Of Mataram City Base On The Local Regulation Number 12 Year 2011." Jurnal IUS: Kajian Hukum Dan Keadilan Volume 2 Nomor 1. pp 28-41. doi:https://dx.doi.org/10.12345/ius.v2i4.155.

Arwana, Yudha Chandra, dan Ridwan Arifin. (2019). "Jalur Mediasi Dalam Penyelesaian Sengketa Pertanahan Sebagai Dorongan Pemenuhan Hak Asasi Manusia." Jambura Law Review Volume 1, no. 2: pp 212-236. doi:https://doi.org/10.33756/jalrev.v1i2.2399.

Asmawati. (2014). "Mediasi Salah Satu Cara Dalam Penyelesaian Sengketa Pertanahan.” INOVATIF: Jurnal Ilmu Hukum Volume 7, no. 1: 54-66.

Denzin, Norman K., Yvonna S. Lincoln (editor), dan Dariyatno (penerjemah). 2009. Handbook of Qualitative Research (Edisi Ketiga). Yogyakarta: Pustaka Pelajar.

Direktur Jenderal Peraturan Perundang-Undangan Kementerian Hukum dan HAM RI. (2016). Peraturan Menteri Agraria dan Tata Ruang / Kepala Badan Pertanahan Nasional RI Nomor 11 Tahun 2016 Tentang Penyelesaian Kasus Pertanahan.

Harsono, Boedi. 2007. Hukum Agraria Indonesia: Sejarah Pembentukan Undang-Undang Pokok Agraria, Isi Dan Pelaksanaannya. Jakarta: Penerbit Djambatan,

Herdiyansyah, Haris. 2012. Metode Kualitatif Untuk Ilmu-Ilmu Sosial. Jakarta: Salemba Humanika.

Huruswati, dkk, Indah. 2012. Evaluasi Program Pembangunan Kesejahteraan Sosial Di Desa Perbatasan - Kalimantan Barat 2012. Jakarta: P3KS Press.

Kusuma, Dadi Arja, Rodliyah, dan Sahnan. (2017). "Sertifikat Hak Milik Atas Tanah Sebagai Alat Bukti Hak Yang Kuat.” Jurnal IUS: Kajian Hukum Dan Keadilan Volume 5 Nomor 2. pp310-321. Agustus.

Lubis, Muhammad Yamin, dan Abdul Rahim Lubis. 2008. Hukum Pendaftaran Tanah. Jakarta: Mandar Maju.

Mahfiana, Layyin. (2017). "Sengketa Kepemilikan Hak Atas Tanah Di Kabupaten Ponorogo.” KODIFIKASIA: Jurnal Penelitian Islam Volume 7, no. 1: 83102. doi:https://doi.org/10.21154/kodifikasia.v7i1.780.

Mudzhar, M Atho. 1998. Pendekatan Studi Islam Dalam Teori Dan Praktek. Yogyakarta: Pustaka Pelajar.

Munir, Mochamad. 1997. "Penggunaan Pengadilan Negeri Sebagai Lembaga Untuk Menyelesaikan Sengketa Dalam Masyarakat." Disertasi, Universitas Airlangga.

Murad, Rusmadi. 1991. Penyelesaian Sengketa Hukum Atas Tanah. Bandung: Mandar Maju.

Nader, dan Todd. 1978. The Disputing Process Law in Ten Societas. New York: Colombia University Press.

Nia Kurniati, dan Efa Laela Fakhriah. (2017). "BPN Sebagai Mediator Dalam Penyelesaian Sengketa Tanah Di Indonesia Pasca PERKABAN No. 11 Tahun 2016." Sosiohumaniora LP2M Unpad Volume 19, No. 2 Juli 2017: 95-105. doi:https://doi.org/10.24198/sosiohumaniora.v19i2.11999.

Nur Shivana. (2017). "Meraba Wujud Hak Asasi Manusia Di Negara Hukum.” Lex Scientia Law Review Volume 1 No. 1. pp. 93-98, Nopember.

Parlindungan, A.P. 1999. Pendaftaran Tanah Di Indonesia Cet. I. Bandung: Mandar Maju.

Rahardjo, Satjipto. 2009. Hukum Progresif Sebuah Sintesa Hukum Indonesia. Yogyakarta: Genta Publishing.

Rosmidah. (2013). "Kepemilikan Hak Atas Tanah Di Indonesia." INOVATIF: Jurnal Ilmu Hukum Volume 6, no. 2: pp 63-77.

Santoso, Urip. 2010. Pendaftaran Dan Peralihan Hak Atas Tanah. Cetakan II. Jakarta: Kencana.

Saputra, Riki Dendih. 2017. "Penyelesaian Sengketa Kepemilikan Tanah Yang Bersertifikat Ganda Menurut Aturan Badan Pertanahan Nasional Di Wilayah Tangerang Selatan.” Skripsi, Fakultas Syariah dan Hukum UIN Syarif Hidayatullah Jakarta.

Sharif, Elza. 2012. Mentuntaskan Sengketa Tanah Melalui Pengadilan Khusus Pertanahan. Jakarta: KPG.

Sumarjono, Maria SW. 2008. Mediasi Sengketa Tanah. Jakarta: Kompas.

Umiyati. (2019). "Penyelesaian Sengketa Batas Tanah Yang Didasarkan Pada Alat Bukti Sertifikat Melalui Alternative Dispute Resolution." Jurnal Spektrum Hukum Volume 6, no. 2: 39-51. doi:https://doi.org/10.35973/sh.v16i2.1181.

Usman, Rachmadi. 2003. Pilihan Penyelesaian Sengketa Di Luar Pengadilan. Bandung: PT. Citra Aditya Bakti.

Wawancara. Desmanto, SH sebagai Kasubsi Pengendalian Pertanahan, di Kantor BPN Kab. Sambas, Tanggal 17 Februari, 2020.

- Dinni Aprilliani, SH sebagai Kasubsi Penanganan Sengketa, Konflik, dan Perkara Pertanahan, di Kantor BPN Kab. Sambas, Tanggal 25 Februari, 2020.

. Edi Supardi sebagai Kasi Penanganan Masalah dan Pengendalian Pertanahan di Kantor BPN Kab. Sambas Tanggal 25 Februari, 2020.

. Fajar Yulianto, SH sebagai Mediator dari Kasi Perdata dan Tata Usaha Negara pada Kejari Sambas, Tanggal 25 Februari, 2020.

. Ilyas sebagai Staf Seksi Penanganan Masalah dan Pengendalian Pertanahan, di Kantor BPN Kab. Sambas, Tanggal 17 Februari, 2020.

Zulkharnain, Dewi. 2013. "Bentuk Penyelesaian Terhadap Sertifikat Ganda (Overlapping) Antara Sertifikat Hak Guna Bangunan Dengan Sertifikat Hak Milik Oleh Badan Pertanahan Nasional Kota Surabaya II." Skripsi, Fakultas Hukum, Universitas Pembangunan Nasional "veteran,”. 